\title{
Idolaku, Sumber Intimacy-ku: Dinamika Celebrity Worship dan Tugas Perkembangan Dewasa Awal Pecinta Kpop
}

\author{
Astri Prabawati Laksono ${ }^{1}$, Afra Hafny Noer ${ }^{2}$ \\ 1,2Fakultas Psikologi Universitas Padjadjaran \\ email: astri13005@mail.unpad.ac.id
}

\section{Artikel INFO}

Diterima:10 Mei 2021

Direvisi 13 September 2021

Disetujui: 11 Oktober 2021

DOI:

http://dx.doi.org/10.24014/ jp.v14i2.12837

Abstrak

Celebrity worship (CW) adalah interaksi satu arah dimana individu terobsesi pada selebriti yang merupakan salah satu cara pembentukan identitas pada remaja, namun banyak ditemukan pada dewasa awal di Indonesia. CW berpotensi menghambat tugas perkembangan dewasa awal yaitu intimacy yang dalam jangka panjang dapat menyebabkan berbagai macam gangguan mental. Pendekatan studi kasus digunakan untuk mengungkap bagaimana CW memberikan warna pada tugas perkembangan dewasa awal pecinta Kpop. Data kualitatif diperoleh melalui wawancara kepada tiga orang perempuan (23-25th) dengan tingkat $\mathrm{CW}$ rendah, sedang, dan tinggi. Tingkatan CW diukur dengan Celebrity Attitude Scale. Analisis tematik dilakukan untuk mengelompokkan tema kecil ke dalam lima tema besar yaitu kegiatan $\mathrm{CW}$, hubungan sosial, hubungan romantis, pekerjaan dan dampak CW. Hasil penelitian menunjukkan bahwa dinamika CW sangat terlihat dalam aspek hubungan sosial dan hubungan romantis. Pada tingkat CW rendah dan sedang, CW menjadi alat yang dapat membantu subjek dalam memenuhi tugas perkembangan dengan memberikan tempat untuk eksplorasi dan alternatif sumber pemenuhan intimacy. Namun pada tingkat tinggi, CW justru menghambat dewasa awal untuk mencapai tugas perkembangan yang disebabkan adanya fantasi berlebihan, perilaku obsesif dan disosiatif yang menyebabkan individu terlepas dari kehidupan nyata dan merasakan krisis berupa rasa kesepian dan perasaan terkucilkan.

Kata-kata kunci: celebrity worship, dewasa awal, kualitatif

\section{The Dynamics of Celebrity Worship and Developmental Task in Early Adult Kpop Lovers}

\begin{abstract}
Celebrity worship (CW) occurs when an individual becomes obsessed with celebrity in a one-way relationship. It is a way of forming identity in adolescents. But in Indonesia, it is mostly found in early adults. CW can potentially hinder early adults to achieve their developmental task: intimacy, which can lead to various kinds of mental disorders. A case study was used to reveal the dynamics of developmental tasks in early adult Kpop lovers. Qualitative data were obtained through interviews with three women (23-25 yo) with low, moderate, and high levels of CW. The CW level is measured with Celebrity Attitude Scale. Thematic analysis was used to obtain five major themes: CW activities, social and romantic relationships, work, and impact of $\mathrm{CW}$. The results showed that the dynamics of $\mathrm{CW}$ were visible in social and romantic relationships. At low and moderate level, CW can help early adults in fulfilling developmental tasks by providing a place for exploration and as an alternative source of intimacy. However, at high level, CW inhibits them from achieving developmental tasks due to excessive fantasies, obsessive and dissociative behaviors that cause them to detach from real life and to experience loneliness and isolation.
\end{abstract}

Keywords: celebrity worship, qualitative, young adult

\section{Pendahuluan}

Saat ini, budaya Korea Selatan sedang menjamur di masyarakat, tak terkecuali musik pop Korea atau Kpop (Lee, 2011). Demam Kpop menjadi sebuah fenomena yang tersebar secara luas dan seringkali menjadi topik diskusi di berbagai macam media seperti media sosial, internet, dan media massa (Ri'aeni, Suci, Pertiwi, \& Sugiarti, 2019) tak terkecuali di Indonesia. Hal ini diperkuat dengan survey yang dilakukan oleh K-pop Radar dimana Indonesia menempati posisi ke-2 dengan jumlah akses konten Kpop terbanyak di Youtube sepanjang tahun 2018 hingga 2019 (9,9\%), posisi ke-3 
dengan jumlah twit terbanyak mengenai idol sepanjang tahun 2019 berdasarkan survey yang dilakukan oleh Twitter, serta negara ke-2 terbanyak yang memutar lagu Kpop di Spotify sepanjang tahun 2020 dengan total 41 miliar kali pemutaran (The Jakarta Post, 2020). Pengaruh dari masuknya Kpop ke Indonesia ditandai dengan munculnya penggemar yang menunjukkan perasaan intens kepada idola mereka yang ditunjukkan melalui kegiatan seperti bergabung dalam fans club, membeli merchandise, datang ke konser, mencari informasi mengenai idola, dan lainlain (Rahman, 2019). Kecintaan pada idola yang dirasakan oleh penggemar disebut juga dengan celebrity worship.

Celebrity worship (CW) merupakan interaksi satu arah dimana individu terobsesi pada selebriti (McCutcheon, Ashe, Houran, \& Maltby, 2003). CW muncul dalam bentuk kontinum dengan satu ujung yang ditandai dengan penggemar yang dengan rajin mengikuti informasi idolanya hingga ujung lainnya yang bersifat patologis (McCutcheon, Lange, \& Houran, 2002). Matlby, Day, McCutcheon, Horan \& Ashe (2006) membagi celebrity worship ke dalam 3 tingkat yaitu: rendah atau entertainment-social, sedang atau intense-personal, dan tinggi atau borderline-pathological. Entertainment-social mencerminkan ketertarikan terhadap idola yang didasarkan kemampuan mereka untuk menghibur. Intense-personal mencerminkan perasaan intens, obsesif dan kompulsif terhadap idola, dan tingkat paling ekstrim, borderline-pathological yang mencerminkan sikap dan perilaku patologis dari individu.

CW mulai muncul pada masa remaja (McCutcheon, Lange, \& Houran, 2002), biasanya pada rentang usia 12 sampai 18 tahun dengan masa puncak antara usia 14 sampai 16 tahun dan semakin menurun saat memasuki masa dewasa (Liu, 2013). Perilaku ini merupakan hal yang wajar ditemukan pada remaja sebagai salah satu media eksplorasi dalam pembentukan identitas (Lavesque, 2012). Dalam rentang yang positif, remaja menyerap dan meniru perilaku serta nilai-nilai yang dibawa oleh idola yang mereka pandang sebagai tokoh yang sukses. Remaja juga mengalami ketidakpastian dan kebingungan terhadap peran baru dan akan melakukan identifikasi kepada orang dewasa atau idola yang dapat membantunya untuk mencari dan menemukan informasi untuk dapat membentuk identitas dirinya (Liu, 2013). CW dilakukan oleh remaja dalam rangka untuk memenuhi tugas perkembangan dan merupakan media yang penting dalam mencapai sense of identity. Hal ini dibutuhkan untuk tugas perkembangan selanjutnya yang berkaitan dengan membangun hubungan yang intim dengan orang lain Apabila sense of identity telah terpenuhi, maka CW akan menurun saat individu memasuki masa dewasa awal (Stever, 2011)

Fenomena yang ditemukan di Indonesia justru bertentangan dengan penelitianpenelitian sebelumnya. Hal ini ditunjukkan oleh survey yang dilakukan oleh salah satu lembaga survey di Indonesia yaitu Jakpat pada tahun 2016. Survey dilakukan kepada 3000 responden dengan rentang usia 15 sampai 45 tahun untuk mendapatkan data demografis dan sebaran penggemar Kpop di Indonesia. Hasil menunjukkan bahwa 43,38\% responden berada pada usia dewasa awal (Fandia, 2016). Hal ini mengindikasikan banyaknya dewasa awal di Indonesia yang diduga belum menyelesaikan tugas perkembangan sebelumnya terkait pembentukan identitas. Dewasa awal pada rentang usia 20 sampai 30 tahun seharusnya sudah membentuk konsep diri yang kuat, mulai membangun kemandirian diri dan ekonomi, mengembangkan karir, memilih pasangan dan membangun hubungan yang intim dengan pasangan, atau bahkan membangun keluarga dan membesarkan anak (Santrock, 2017). Selain itu, menurut model Psikososial Erik Erikson masa dewasa awal masuk ke dalam tahap intimacy versus isolation dengan tugas perkembangan utama membangun relasi yang bersifat intim (Santrock, 2017) yang dicirikan dengan adanya kepercayaan, 
keterbukaan, komitmen, dan kepedulian (Liu, 2013). Adanya identitas yang kuat merupakan syarat penting dalam membangun intimacy dalam hubungan romantis pada dewasa awal. Individu yang tidak yakin akan identitas mereka akan menghindar dari keintiman psikososial atau justru putus asa dalam mencari keintiman, yang berakhir pada hubungan yang tidak berarti (Feist \& Feist, 2018).

Lebih jauh lagi, salah satu studi menunjukkan bahwa celebrity worshiper cenderung menunjukkan ketidakmampuan dalam membangun hubungan sosial (McCutcheon, Ashe, Houran, \& Maltby, 2003). Mereka memilih idola sebagai bentuk interaksi yang lebih mudah karena kemungkinan penolakan yang kecil (McCutcheon, Ashe, Houran, \& Maltby, 2003). Ketidakmampuan dalam membangun hubungan sosial menyebabkan dewasa awal masuk ke dalam krisis yaitu isolation yang ditandai dengan munculnya rasa kesepian (Santrock, 2017). Dalam jangka panjang, hal ini dapat memunculkan gangguan mental seperti stress, depresi, atau bahkan bunuh diri (Mushtaq, Shoib, Shah, \& Mushtaq, 2014).

Penelitian CW pada dewasa awal di Indonesia masih jarang dilakukan.Beberapa di antaranya mencoba mengungkapkan perilaku CW yang khas dari dewasa awal (Cahyani \& Purnamasari, 2018) (Dewi \& Indrawati, 2019), sedangkan penelitian yang mencoba untuk mengaitkan $\mathrm{CW}$ dengan tugas perkembangan baru dilakukan oleh Darfiyanti \& Putra (2012) pada aspek hubungan romantis dan belum menyentuh aspek lain seperti hubungan sosial, baik dalam pertemanan atau keluarga, maupun aspek pekerjaan, yang juga merupakan aspek-aspek penting pada dewasa awal (Santrock, 2017). Selain itu, responden penelitian tersebut termasuk dalam entertainment-social (rendah) dan intense-personal (sedang) saja, sehingga dinamika dan perbedaan antar setiap tingkat belum tergambarkan dengan jelas dan menjadi saran untuk penelitian selanjutnya
(Darfiyanti \& Putra, 2012). Berdasarkan hal tersebut, perlu dilakukan studi lanjutan yang bertujuan untuk menjelaskan CW dan kaitannya dengan aspek-aspek tugas perkembangan dewasa awal pada pecinta Kpop dari seluruh tingkat CW. Penelitian ini berusaha menjawab pertanyaan: bagaimana dinamika tugas perkembangan dewasa awal di kalangan pecinta Kpop?

\section{Metode}

Metode kualitatif dengan pendekatan studi kasus dengan pendekatan theory-driven digunakan dengan tujuan untuk memahami suatu fenomena unik secara lebih mendalam (Creswell \& Poth, 2018). Dalam hal ini peneliti ingin melihat dinamika pemenuhan tugas perkembangan dewasa awal pada pecinta Kpop.

\section{Subjek Penelitian}

Populasi dalam peneltian ini adalah dewasa awal dengan rentang usia 20 sampai 30 tahun dan merupakan pecinta Kpop yang mengikuti perkembangan Kpop dan menikmati konten-konten di dalamnya. Subjek dipilih berdasarkan ketersediaan di lingkungan yang sesuai dengan kriteria penelitian. Subjek terdiri dari tiga perempuan dengan masingmasing usia $\mathrm{R} 1=23$ tahun, $\mathrm{R} 2=25$ tahun, dan R3 = 25 tahun. Tingkat CW subjek diukur dengan menggunakan alat ukur Celebrity Attitude Scale (CAS) yang telah diadaptasi ke dalam bahasa Indonesia (Envira, 2019). Hasil menunjukkan bahwa R1 berada pada tingkat sedang atau intense-personal ( $\mathrm{X}=$ 97), R2 pada tingkat tinggi atau borderlinepathological $(X=110)$, dan R3 berada pada tingkat rendah atau entertainment-social $(X=52)$. Seluruh subjek memiliki lebih dari satu idola yang seluruhnya berjenis kelamin laki-laki. R1 dan R2 sudah menyukai Kpop sejak SMP sekitar 10-11 tahun, sedangkan R3 mulai pada tahun 2017 di tingkat akhir perkuliahan atau sekitar 4 tahun.

Teknik Pengambilan Data 
Subjek terlebih dahulu diberikan informasi terkait penelitian dan mengisi informed consent secara daring. Kemudian subjek diminta untuk mengisi kuesioner Celebrity Attitude Scale (CAS) untuk menentukan tingkat CW. Selanjutnya pengambilan data dilakukan melalui 3 sumber yaitu: (1) wawancara semi struktural dengan pertanyaan-pertanyaan mengacu pada tugas perkembangan dewasa awal, (2) observasi terhadap ekspresi dan perilaku yang ditunjukkan subjek selama proses wawancara, dan (3) bukti visual berupa video barang-barang koleksi terkait idola yang dimiliki oleh subjek. Penggunaan tiga teknik pengambilan data atau triangulasi dilakukan untuk pemeriksaan silang dan memberikan konfirmasi serta kelengkapan data sehingga menghasilkan penjelasan yang seimbang dan meningkatkan kepercayaan (Yeasmin \& Rahman, 2012).

Tabel 1. Contoh Pertanyaan Wawancara

\begin{tabular}{cl}
\hline No & \multicolumn{1}{c}{ Pertanyaan } \\
\hline 1 & Bagaimana awal mula Anda menyukai Kpop? \\
\hline 2 & Bisa ceritakan pengalaman Anda melakukan aktivitas yang berkaitan dengan Kpop? \\
\hline 3 & $\begin{array}{l}\text { Apakah kecintaan Anda terhadap Kpop mempengaruhi hubungan sosial Anda } \\
\text { dengan teman dan keluarga? } \\
\text { Jika "Ya", bagaimana pengaruhnya bagi Anda? }\end{array}$ \\
\hline 4 & $\begin{array}{l}\text { Apakah kecintaan Anda terhadap Kpop mempengaruhi hubungan romantis Anda } \\
\text { atau pandangan Anda terhadap hubungan romantis? } \\
\text { Jika "Ya", bagaimana pengaruhnya bagi Anda? }\end{array}$ \\
\hline 5 & $\begin{array}{l}\text { Apakah kecintaan Anda terhadap Kpop mempengaruhi nilai-nilai hidup Anda? } \\
\text { Jika "Ya", bagaimana pengaruhnya bagi Anda? }\end{array}$ \\
\hline
\end{tabular}

\section{Teknik Analisis Data}

Peneliti menggunakan teknik analisis tematik dari Braun \& Clarke (2012) dengan mengelompokkan tema kecil yang telah terkumpul ke dalam tema besar yang telah ditentukan.

\section{Hasil}

Dalam penelitian ini terdapat lima tema utama yaitu kegiatan CW, hubungan sosial, hubungan romantis, pekerjaan, serta dampak yang dirasakan. Tema-tema ini mengacu pada teori terkait area utama dalam tugas perkembangan dewasa awal. Di dalam tema tersebut terdapat beberapa subtema lain yang menjelaskan dinamika masing-masing tema.

\section{Kegiatan Celebrity Worship}

Hasil menunjukkan bahwa terdapat perbedaan intensitas dan frekuensi pada setiap kegiatan yang dilakukan subjek dimana semakin tinggi tingkat $\mathrm{CW}$, maka semakin intens perasaan dan frekuensi serta jenis kegiatan yang dilakukan. R2 dengan tingkat borderline-pathological (tinggi) menunjukkan intensitas perasaan, jenis dan jumlah kegiatan yang lebih tinggi dibandingkan dengan subjek lain. Hal ini juga didukung dari hasil observasi dimana subjek menunjukkan berbagai macam ekspresi saat membicarakan tentang idola, misalnya marah dan mencibir ketika menceritakan pengalaman beradu pendapat dengan fans lain saat idola diejek dan ekspresi tertarik saat membicarakan prestasi idola sekaligus secara sukarela menujukkan koleksi merchandise yang ia miliki sebanyak satu lemari kecil. Selain itu R2 juga menunjukkan perasaan sedih yang mengganggu kegiatan sehari-hari saat idola mengalami musibah.

R1 dengan tingkat intense-personal (sedang) juga menunjukkan perasaan yang intens terhadap idola, meskipun intensitasnya tidak setinggi R2. Hal ini didukung dengan hasil observasi dan bukti fisik dimana R1 menampilkan ekspresi tertarik dan bersemangat saat membahas idola serta 
menunjukkan satu persatu koleksi yang ia miliki sebanyak satu lemari besar dan menceritakan bagaimana ia mendapatkan barang tersebut, serta meja belajarnya yang penuh dengan barang-barang yang berkaitan dengan idola. Hanya saja perasaan yang dirasakan terhadap idola tidak mempengaruhi kegiatan sehari-hari R1. la juga dapat mengontrol perilaku mencari informasi tentang idolanya (fangirling) dan tidak terlibat perselisihan dengan penggemar lain untuk melindungi idola Kpop nya (fan war) karena memiliki keyakinan bahwa Kpop seharusnya menjadi hiburan, bukan hal yang membuat perpecahan atau menyebarkan kebencian.

Pada R3 dengan tingkat entertainmentsocial (rendah), subjek menggunakan Kpop sebagai hiburan. la hanya menikmati karya dan perjalanan hidup idola di waktu istirahatnya. Hal ini juga yang menyebabkan R3 tidak memiliki perasaan intens terhadap idolanya. Selain itu, R3 juga tidak mengumpulkan merchandise atau mengikuti berbagai macam kegiatan yang berkaitan dengan idola seperti R1 dan R2.

\section{Tabel 2. Perbandingan Kegiatan Celebrity Worship}

\begin{tabular}{|c|c|c|c|}
\hline Jenis Kegiatan & $\begin{array}{c}\text { R1 } \\
\text { Intense-Personal } \\
\text { (Sedang) }\end{array}$ & $\begin{array}{c}\text { R2 } \\
\text { Borderline- } \\
\text { Pathological } \\
\text { (Tinggi) }\end{array}$ & $\begin{array}{c}\text { R3 } \\
\text { Entertainment-Social } \\
\text { (Rendah) }\end{array}$ \\
\hline Menonton konser & 6 kali & 7 kali & Tidak \\
\hline Mengikuti fans club & Tidak & Ya & Tidak \\
\hline $\begin{array}{l}\text { Mengikuti acara yang } \\
\text { berhubungan dengan } \\
\text { idola }\end{array}$ & Mengikuti kumpul Kpop & $\begin{array}{ll}- & \text { Menjadi pengurus } \\
\text { fans club dari boyband } \\
\text { idola secara sukarela } \\
\text { - Mengikuti kumpul } \\
\text { Kpop }\end{array}$ & Tidak \\
\hline $\begin{array}{c}\text { Mengoleksi } \\
\text { merchandise idola }\end{array}$ & $\begin{array}{l}\text { - Membeli dan } \\
\text { mengumpulkann } \\
\text { merchandise idola } \\
\text { - Memiliki pakaian } \\
\text { dengan identitas idola }\end{array}$ & $\begin{array}{l}\text { Membeli dan } \\
\text { mengumpulkan } \\
\text { merchandise idola } \\
\text { Mencari pakaian } \\
\text { dengan model atau } \\
\text { motif yang mirip } \\
\text { dengan idola } \\
\end{array}$ & Tidak \\
\hline $\begin{array}{l}\text { Perasaan intens } \\
\text { terhadap idola }\end{array}$ & $\begin{array}{l}\text { Wawancara : } \\
\text { - Merasa bersalah } \\
\text { karena tidak } \\
\text { mendukung idola jika } \\
\text { tidak membeli album } \\
\text { Merasa bersalah } \\
\text { karena tidak bisa } \\
\text { menolong idola yang } \\
\text { bunuh diri } \\
\text { Observasi : } \\
\text { Saat menceritakan } \\
\text { rasa bersalahnya } \\
\text { karena tidak } \\
\text { mendukung idola, } \\
\text { subjek tidak } \\
\text { menunjukkan ekspresi } \\
\text { apapun } \\
\text { Nada bicara dan } \\
\text { ekspresi wajah serius } \\
\text { (mengernyitkan alis) } \\
\text { saat menceritakan } \\
\text { peristiwa bunuh diri } \\
\text { dari idola }\end{array}$ & $\begin{array}{l}\text { Wawancara : } \\
\text { - Merasa sangat sedih } \\
\text { saat idola terkena } \\
\text { serangan panik hingga } \\
\text { mengganggu kegiatan } \\
\text { sehari-hari R2 } \\
\text { - Pikiran berulang } \\
\text { tentang idola bahkan } \\
\text { ketika tidak ingin } \\
\text { Observasi : } \\
\text { Ekspresi wajah subjek } \\
\text { sangat sedih (bibir } \\
\text { menekuk ke bawah, } \\
\text { alis agak mengkerut } \\
\text { pundak turun), suara } \\
\text { bicara melemah, } \\
\text { dan diselingi helaan } \\
\text { napas berat saat } \\
\text { menceritakan idolanya } \\
\text { terkena serangan } \\
\text { panik } \\
\text { Ketika menceritakan } \\
\text { frekuensi mengingat } \\
\text { idola, ekspresi } \\
\text { berubah cerah dan } \\
\text { suaranya keras } \\
\text { bersemangat } \\
\end{array}$ & $\begin{array}{l}\text { Wawancara : } \\
\text { Prihatin saat idola } \\
\text { dikeluarkan dari grupnya } \\
\text { Observasi : } \\
\text { Nada bicara subjek } \\
\text { sedikit naik dengan } \\
\text { sesekali tersenyum } \\
\text { ketika menceritakan } \\
\text { pengalaman idolanya } \\
\text { keluar dari grup. }\end{array}$ \\
\hline
\end{tabular}


Kegiatan yang mencerminkan perasaan suka terhadap idola

\section{Wawancara :}

- Membicarakan idola dengan teman dekat

- Mencari tahu informasi melalui sumber resmi (fansite) dan tidak resmi (media sosial)

- Menonton dan mendengarkan musik atau acara yang berhubungan dengan idola

- Menceritakan kekesalan terhadap fans club lain yang menjelekkan idola kepada teman dekat

- Mengikuti dance challenge di media sosial bersama keluarga

\section{Observasi :}

- Sepanjang bercerita, subjek seringkali tertawa dengan nada suara yang ceria

- Subjek menceritakan dance challenge bersama keluarga sambil memperagakan beberapa gerakan dance. Ekspresi bangga keetika mengatakan bahwa videonya di-repost oleh idola

\section{Wawancara}

- Terlibat dalam fan war

- Mencari tahu informasi melalui sumber resmi (fan site) dan tidak resmi (media sosial)

- Membuat video kompilasi idola

- Mengirimkan pesan positif untuk memberikan semangat di media sosial

- Maraton drama idola di waktu luang (total 500 drama yang sudah ditonton)

- Menonton dan mendengarkan musik atau acara yang berhubungan dengan idola

\section{Observasi :}

- Ekspresi marah, suara keras sambil sesekali mencibir dan mengibaskan tangan seperti mengusir saat menceritakan pengalaman fan war dengan penggemar lain

- Ekspresi wajah bangga sambil menggerak-gerakkan tangannya (seperti menyibakkan kerudung) ketika menceritakan prestasi idola

- Tersenyum sambil menunjukkan pesan yang ia kirimkan untuk menyemangati idola

Wawancara :

Saat istirahat dan senggang

Waktu fangirling

\section{Observasi :}

Tidak menunjukkan ekspresi atau perilaku tertentu
Wawancara :

Kapan saja dan dimana saja

\section{Observasi :}

Menjawab dengan cepat "Kapan aja dan dimana aja dong" sambil tertawa keras
Wawancara :

- Mencari tahu informasi melalui sumber resmi (fan site) dan tidak resmi (media sosial)

- Membicarakan idola dengan teman dekat

- Mengucapkan selamat ulang tahun pada salah satu idola (1 kali)

- Memberikan semangat di media sosial idola saat idola sedang ada masalah

- Menonton dan mendengarkan musik atau acara yang berhubungan dengan idola

\section{Observasi :}

Subjek tidak menunjukkan ekspresi atau perilaku yang mencolok.

\section{Hubungan Sosial}

Pada aspek hubungan sosial, seluruh subjek menggunakan Kpop sebagai salah
Perbedaan terlihat dari waktu penggunaan dan objek interaksi dalam hubungan sosial. 
R1 dengan tingkat intense-personal (sedang), menggunakan Kpop sebagai media untuk membangun komunikasi di awal interaksi dengan orang lain dan media yang mempererat hubungan dengan orang terdekatnya. R1 mendapatkan respon positif dari lingkungan berupa hubungan yang semakin erat.

Pada R2 dengan tingkat borderlinepathological (tinggi), Kpop juga menjadi media untuk membangun interaksi awal dengan orang lain. Namun tingginya frekuensi dan intensitas fangirling yang membuat R2 seringkali menenggelamkan diri dengan kegiatan fangirling yang menyebabkan ia mendapatkan respon negatif dari lingkungan.

Pada R3 dengan tingkat entertainmentsocial (rendah), Kpop hanya digunakan sebagai salah satu topik pembicaraan dengan teman dekat. R3 tidak menggunakan Kpop untuk membangun interaksi dengan orang lain atau masuk ke lingkungan sosial baru. Oleh karena itu, ia tidak pernah mendapatkan respon negatif dari orang lain.

Tabel 3. Hubungan Sosial

\begin{tabular}{|c|c|c|c|}
\hline \multirow[b]{2}{*}{ Subtema } & R1 & R2 & R3 \\
\hline & $\begin{array}{l}\text { Intense-Personal } \\
\text { (Sedang) }\end{array}$ & $\begin{array}{l}\text { Borderline- } \\
\text { Pathological } \\
\text { (Tinggi) }\end{array}$ & $\begin{array}{l}\text { Entertainment-Social } \\
\text { (Rendah) }\end{array}$ \\
\hline \multirow[t]{2}{*}{$\begin{array}{l}\text { Kpop sebagai } \\
\text { media membangun } \\
\text { hubungan sosial }\end{array}$} & $\begin{array}{l}\text { Wawancara : } \\
\text { - Mengikuti kumpul Kpop } \\
\text { untuk mencari teman baru } \\
\text { - Kpop menjadi alat } \\
\text { komunikasi yang } \\
\text { mempererat hubungan } \\
\text { keluarga } \\
\text { - Kpop menjadi topik } \\
\text { pembuka interaksi sosial } \\
\text { sebelum masuk ke topik } \\
\text { yang lebih dalam } \\
\text { - Menggunakan pakaian } \\
\text { yang menunjukkan } \\
\text { kesukaan pada idola saat } \\
\text { hari pertama masuk kuliah } \\
\text { untuk mencari teman }\end{array}$ & $\begin{array}{l}\text { Wawancara : } \\
\text { - Mencari teman di } \\
\text { media sosial melalui } \\
\text { hashtag Kpop dan } \\
\text { berbalas komentar } \\
\text { - Kpop menjadi topik } \\
\text { pembuka interaksi } \\
\text { sosial sebelum } \\
\text { masuk ke topik yang } \\
\text { lebih dalam }\end{array}$ & $\begin{array}{l}\text { Wawancara : } \\
\text { - Kpop sebagai salah } \\
\text { satu topik pembicaraan } \\
\text { dengan teman dekat } \\
\text { - } \\
\text { Mengobservasi } \\
\text { interaksi antar idola } \\
\text { sebagai salah satu } \\
\text { media belajar interaksi }\end{array}$ \\
\hline & $\begin{array}{l}\text { Observasi : } \\
\text { - Menceritakan ceritanya } \\
\text { dengan tersenyum- } \\
\text { senyum } \\
\text { - Menunjukkan lokasi } \\
\text { logo di baju dengan } \\
\text { nada bangga sambil } \\
\text { sesekali tertawa ketika } \\
\text { menceritakan ceritanya } \\
\text { memakai pakaian yang } \\
\text { menunjukkan kesukaan } \\
\text { nada idola saat kuliah }\end{array}$ & $\begin{array}{l}\text { Observasi : } \\
\text { Tidak menunjukkan } \\
\text { ekspersi atau perilaku } \\
\text { khusus }\end{array}$ & $\begin{array}{l}\text { Observasi : } \\
\text { Tidak menunjukkan } \\
\text { ekspersi atau perilaku } \\
\text { khusus }\end{array}$ \\
\hline
\end{tabular}


Respon dari lingkungan
Wawancara :

- Mendapatkan sambutan hangat dari teman-teman baru

- Komunikasi dan hubungan keluarga semakin erat

\section{Observasi :}

Nada bicara dan ekspresi subjek ceria, saat menceritakan hubungan dengan saudara yang semakin erat
Wawancara :

- Mendapat komentar negatif dari temanteman sebaya secara langsung

- Mendapatkan komentar negatif di media sosial akibat kegiatan CW

- Teman sebaya membicarakannya di belakang

- Ditinggalkan teman sebaya dan baik di dunia nyata maupun di media sosial (unfollow)

- Keluarga memberikan komentar negatif terkait perilaku borosnya karena Kpop

\section{Observasi :}

- Ketika menceritakan komentar dan perlakuan negatif dari teman, suara subjek melemah dengan beberapa jeda, ekspresi wajah sendu, sesekali tersenyum tapi dengan ekspresi sedih

- Menunjukkan ekspresi kesal dan menyatakan ketidaksetujuannya terhadap sikap orang tua ketika becerita tentang komentar negatif yang ia dapat dari orang tuanya

\section{Wawancara :}

Pertemanan dengan teman dekat menjadi semakin erat

\section{Observasi :}

Bercerita sambil tertawa
Respons yang ditunjukkan subjek

\section{Wawancara :}

Terus menggunakan Kpop sebagai media seperti saat ini

\section{Observasi :}

Tidak menunjukkan ekspersi atau perilaku khusus

\section{Wawancara :}

- Menarik diri dari teman sebaya di kuliah dan mencari lingkungan yang sama-sama menyukai Kpop

- Merasa canggung dan bingung membuka pembicaraan dengan teman lama yang tidak suka Kpop

\section{Observasi :}

Mengangkat pundak saat mengatakan "Yaudah, mau gimana lagi" saat menceritakan bahwa subjek mencari lingkungan baru 


\begin{tabular}{llll}
\hline & Wawancara : & & \\
& - Senang karena Kpop & Wawancara : & \\
& membawa banyak manfaat & - Merasa kesepian & \\
& - Senang menemukan & karena merasa & Wawancara : \\
& lingkungan yang & teman-teman di dunia & Senang karena hubungan \\
memahami perilaku & nyata (non-Kpop) & dengan teman dekat \\
Dampak psikologis & fangirling-nya & menjauhinya & menjadi semakin erat. \\
yang dirasakan & Observasi : & Observasi : & Observasi : \\
& Tersenyum-senyum sambil & Ekspresi subjek sedih, & Berbicara sambil \\
& memegang menggerak- & suara subjek menjadi & tersenyum \\
& gerakan tangan (seperti & pelan saat berkata & \\
& menari) & bahwa ia kesepian & \\
\hline
\end{tabular}

\section{Hubungan Romantis}

Pada aspek hubungan romantis, seluruh subjek menyatakan belum memiliki pasangan. Dari tabel 3, dapat dilihat bahwa hanya R2 dengan tingkat borderline-pathological (tinggi) yang merasakan kesulitan dalam hubungan romantis. Seluruh subjek menyatakan bahwa idola mencerminkan kriteria pasangan ideal. Namun hanya R1 dengan tingkat intensepersonal (sedang) dan R2 dengan tingkat borderline-pathological (tinggi) idola juga memberikan pengaruh pada standar ideal pasangan. Selain itu, fantasi idola sebagai soulmate hanya muncul pada R1 dengan tingkat intense-personal (sedang) dan R2 dengan tingkat borderline-pathological (tinggi), namun tidak pada R3 dengan tingkat entertainment-social (rendah). Pada R2 fantasi muncul dengan frekuensi dan intensitas yang lebih tinggi dibandingkan dengan R1. Selain itu, baik R1 dan R2 memiliki lebih dari satu idola laki-laki, namun hanya R2 yang memperlakukan idolanya seperti pasangan di dunia nyata.

Tabel 4. Hubungan Romantis

\begin{tabular}{|c|c|c|c|}
\hline & R1 & R2 & R3 \\
\hline Subtema & $\begin{array}{l}\text { Intense-Personal } \\
\text { (Sedang) }\end{array}$ & $\begin{array}{c}\text { Borderline-Pathological } \\
\text { (Tinggi) }\end{array}$ & $\begin{array}{l}\text { Entertainment-Social } \\
\text { (Rendah) }\end{array}$ \\
\hline $\begin{array}{l}\text { Pengalaman } \\
\text { berpacaran }\end{array}$ & Belum pernah & Beberapa kali & Satu kali \\
\hline Pasangan saat ini & Belum punya & Belum punya & Belum punya \\
\hline \multirow[t]{2}{*}{$\begin{array}{l}\text { Kriteria pemilihan } \\
\text { pasangan }\end{array}$} & $\begin{array}{l}\text { Wawancara : } \\
\text { Karakteristik pasangan } \\
\text { ideal dan idola saling } \\
\text { mempengaruhi satu sama } \\
\text { lain }\end{array}$ & $\begin{array}{l}\text { Wawancara: } \\
\text { - Karakteristik idola } \\
\text { memiliki kemiripan } \\
\text { satu sama lain dan } \\
\text { mirip dengan kriteria } \\
\text { pasangan dunia nyata } \\
\text { - Ingin memiliki pasangan }\end{array}$ & $\begin{array}{l}\text { Wawancara: } \\
\text { Karakteristik pasangan } \\
\text { ideal tercermin dari } \\
\text { karakteristik idola, namun } \\
\text { kriteria pasangan ideal di } \\
\text { dunia nyata tidak harus } \\
\text { seperti idola. }\end{array}$ \\
\hline & $\begin{array}{l}\text { Observasi : } \\
\text { Menjelaskan sambil } \\
\text { tersenyum malu }\end{array}$ & $\begin{array}{l}\text { seperti idola } \\
\text { Observasi : } \\
\text { Menjelaskan sambil } \\
\text { tertawa }\end{array}$ & $\begin{array}{l}\text { Observasi : } \\
\text { Subjek tidak menunjukkan } \\
\text { ekspresi tertentu saat } \\
\text { menjelaskan }\end{array}$ \\
\hline
\end{tabular}


Menganggap idola sebagai soulmate
Wawancara :

Membayangkan idola sebagai pasangan karena belum menemukan pasangan ideal di dunia nyata

\section{Observasi :}

Menjelaskan sambil terkekeh, tangannya dikibas-kibaskan di depan wajah saat bercerita ia membayangkan idola sebagai pasangan

\section{Wawancara :}

- Berkali-kali mengingatkan bahwa ia memiliki pasangan idola Kpop saat merasa kesepian

- Membayangkan idola sebagai pasangan karena belum menemukan pasangan ideal

- Memperlakukan idola seperti pasangan di dunia nyata

\section{Observasi :}

Menjelaskan sambil tertawa keras, sering mengatakan "Duh, malu gue", sering membetulkan posisi duduk dan posisi kerudung saat bercerita tentang idola sebagai soulmate

\section{Wawancara :}

Ya, karena :

- Merasa bingung dengan tuntutan memiliki hubungan romantis

- Tidak bisa membuka diri dan takut pasangan tidak menerima dirinya

- Terlalu lama menenggelamkan diri dengan memikirkan Kpop membuat R2 tidak tahu cara membangun intimacy dengan orang lain di dunia nyata

Wawancara :

Tidak (Memiliki orang yang disukai)

Kpop sebagai tempat pelarian

\section{Observasi :}

Subjek tidak menunjukkan ekspresi atau perilaku tertentu saat menjelaskan
- Tidak tertarik mencari pasangan karena tidak bisa lagi membedakan rasa suka terhadap idola dan kepada orang pada kehidupan nyata.

\section{Observasi :}

- Suara subjek pelan, tersenyum namun dengan ekspresi sedih, posisi duduk sedikit membungkuk

- Beberapa kali jeda dan menghembuskan napas berat saat menceritakan ketidakmampuan membuka dan ketakutannya

\section{Wawancara :}

Tidak (Belum ingin memiliki pasangan karena fokus pada pekerjaan)

\section{Observasi :}

Subjek tidak menunjukkan ekspresi tertentu saat menjelaskan 
Pekerjaan

Pada aspek pekerjaan, subjek memiliki pandangan berbeda-beda terkait $\mathrm{CW}$ yang ia lakukan. R1 menunjukkan ketertarikan untuk menjadikan ketertarikannya terhadap Kpop sebagai salah satu sumber pekerjaan di masa depan. Sedangkan R2 dan R3 tidak memiliki ketertarikan untuk menjadikan Kpop sebagai alternatif pekerjaan.

Tabel 5. Pekerjaan

\begin{tabular}{|c|c|c|c|}
\hline \multirow[b]{2}{*}{ Subtema } & R1 & R2 & R3 \\
\hline & $\begin{array}{c}\text { Intense- Personal } \\
\text { (Sedang) }\end{array}$ & $\begin{array}{c}\text { Borderline-Pathological } \\
\text { (Tinggi) }\end{array}$ & $\begin{array}{l}\text { Entertainment-Social } \\
\text { (Rendah) }\end{array}$ \\
\hline $\begin{array}{c}\text { Kpop } \\
\text { sebagai } \\
\text { pekerjaan }\end{array}$ & $\begin{array}{l}\text { Wawancara : } \\
\text { Tidak menjadikan Kpop } \\
\text { sebagai pekerjaan utama, } \\
\text { namun ingin menjadi Kpop } \\
\text { influencer di masa depan } \\
\text { - Pernah mencoba mendaftar } \\
\text { pekerjaan sebagai content } \\
\text { creator di media Kpop } \\
\text { Indonesia }\end{array}$ & $\begin{array}{l}\text { Wawancara : } \\
\text { Tidak berminat untuk } \\
\text { menggunakan Kpop sebagai } \\
\text { sumber pekerjaan }\end{array}$ & $\begin{array}{l}\text { Wawancara : } \\
\text { Kpop sebagai inspirasi } \\
\text { fashion } \\
\text { Observasi : } \\
\text { Tidak menunjukkan espresi } \\
\text { atau perilaku khusus }\end{array}$ \\
\hline \multicolumn{2}{|c|}{$\begin{array}{l}\text { Dampak Celebrity Worship } \\
\text { Kpop memberikan perubahan pada diri } \\
\text { subjek baik positif maupun negatif. Tiga subjek } \\
\text { merasa bahwa Kpop membantu mereka dalam } \\
\text { meningkatkan kepercayaan diri dan suasana } \\
\text { hati mereka melalui kegiatan-kegiatan yang } \\
\text { dibawa konten Kpop. Pada R1, Kpop juga } \\
\text { digunakan sebagai alat untuk mengasah hobi. }\end{array}$} & \multicolumn{2}{|c|}{$\begin{array}{l}\text { Sedangkan pada R2 dan R3 merasa bahwa } \\
\text { mengenal Kpop membuatnya lebih terbuka } \\
\text { dalam memandang perbedaan. Disamping } \\
\text { manfaat yang dirasakan, ada juga dampak } \\
\text { negatif dari CW pada tiga subjek antara lain } \\
\text { boros, munculnya steoreotype terhadap orang } \\
\text { lain dan kurangnya waktu istirahat. Pada R2, } \\
\mathrm{CW} \text { digunakan juga sebagai tempat pelarian } \\
\text { dari tugas dan kehidupan nyata. }\end{array}$} \\
\hline
\end{tabular}

Tabel 6. Dampak Celebrity Worship

\begin{tabular}{|c|c|c|c|}
\hline \multirow[b]{2}{*}{ Subtema } & R1 & $\mathbf{R 2}$ & R3 \\
\hline & $\begin{array}{l}\text { Intense- Personal } \\
\text { (Sedang) }\end{array}$ & $\begin{array}{c}\text { Borderline-Pathological } \\
\text { (Tinggi) }\end{array}$ & Entertainment-Social (Rendah) \\
\hline $\begin{array}{l}\text { Dampak } \\
\text { Positif }\end{array}$ & $\begin{array}{l}\text { Wawancara : } \\
\text { - } \quad \text { Belajar grooming } \\
\text { - } \text { hobi } \\
\text { - } \quad \text { Mencontoh kerja keras } \\
\text { dan semangat idola untuk } \\
\text { mencapai kesuksesan } \\
\text { - } \quad \text { Memahami bahwa } \\
\text { rasa lelah dan masalah } \\
\text { yang datang adalah hal } \\
\text { manusiawi } \\
\text { - Mendengarkan lagu Kpop } \\
\text { untuk mengubah suasana } \\
\text { hati negatif menjadi positif } \\
\text { Observasi : } \\
\text { Ekspresi wajah ceria saat } \\
\text { menceritakan lagu Kpop }\end{array}$ & $\begin{array}{l}\text { Wawancara : } \\
\text { - } \quad \text { Lebih open minded dan } \\
\text { menghargai perbedaan } \\
\text { Belajar grooming sehingga } \\
\text { lebih bisa menghargai diri } \\
\text { sendiri dan percaya diri } \\
\text { - } \quad \text { Memahami bahwa rasa lelah } \\
\text { dan masalah yang datang } \\
\text { adalah hal manusiawi yang } \\
\text { dihadapi semua orang. } \\
\text { - Mendengarkan lagu Kpop } \\
\text { untuk mengubah suasana hati } \\
\text { negatif menjadi positif } \\
\text { Observasi : } \\
\text { - Menunjukkan riasan } \\
\text { eyeshadow di mata saat } \\
\text { menjelaskan tentang grooming } \\
\text { Ekspresi dan nada bicara } \\
\text { subjek santai (sesekali } \\
\text { tersenyum dan diselingi } \\
\text { candaan) }\end{array}$ & $\begin{array}{l}\text { Wawancara : } \\
\text { - } \quad \text { Menggunakan kisah } \\
\text { idola dan makna lagu } \\
\text { sebagai pengingat untuk } \\
\text { mengapresiasi dan mencintai } \\
\text { diri sendiri } \\
\text { - } \quad \text { Meningkatkan kepercayaan } \\
\text { diri } \\
\text { - } \quad \text { Lebih open minded } \\
\text { - } \quad \text { Belajar grooming } \\
\text { - Mendengarkan lagu Kpop } \\
\text { untuk mengubah suasana } \\
\text { hati negatif menjadi positif } \\
\text { - Memahami bahwa rasa lelah } \\
\text { dan masalah yang datang } \\
\text { adalah hal manusiawi } \\
\text { Observasi : } \\
\text { Nada bicara menjadi cepat, } \\
\text { ekspresi wajah bersemangat, } \\
\text { mencondongkan badan ke } \\
\text { depan saat menceritakan } \\
\text { dampak positif yang ia rasakan }\end{array}$ \\
\hline
\end{tabular}




\begin{tabular}{|c|c|c|c|}
\hline Negatif & $\begin{array}{l}\text { Wawancara : } \\
\text { - Adanya pandangan negatif } \\
\text { terhadap orang lain yang } \\
\text { mengikuti fans club tertentu } \\
\text { dan mencegahnya berteman } \\
\text { dengan orang tersebut } \\
\text { - Boros karena sering } \\
\text { membeli merchandise } \\
\text { Observasi : } \\
\text { - Ekspresi subjek serius } \\
\text { dengan nada bicara yang } \\
\text { sedikit rendah ketika } \\
\text { menceritaka tentang } \\
\text { pandangan negative yang } \\
\text { ia miliki } \\
\text { - Subjek tersenyum-senyum } \\
\text { sambil memainkan pulpen } \\
\text { ketika mengatakan bahwa } \\
\text { dirinya boros }\end{array}$ & $\begin{array}{l}\text { Wawancara : } \\
\text { - } \quad \text { Adanya pandangan negatif } \\
\text { terhadap orang lain yang } \\
\text { mengikuti fans club tertentu } \\
\text { dan mencegahnya berteman } \\
\text { dengan orang tersebut } \\
\text { - } \quad \text { Boros karena sering membeli } \\
\text { kuota dan merchandise } \\
\text { - Tidak bisa mengatur waktu } \\
\text { - Melakukan fangirling sebagai } \\
\quad \text { pelarian dari skripsi, tugas, dan } \\
\text { kehidupan nyata sementara } \\
\text { - Membuat } 2 \text { akun sosial media } \\
\text { sebagai untuk memisahkan } \\
\text { Kpop dan teman } \\
\text { Observasi : } \\
\text { Ekspresi wajah subjek serius } \\
\text { sambil menggerak-gerakan tangan } \\
\text { selama menjawab. la menjelaskan } \\
\text { dengan panjang terutama ketika } \\
\text { menyebutkan bahwa ia membuat } 2 \\
\text { akun sosial media }\end{array}$ & $\begin{array}{l}\text { Wawancara : } \\
\text { Kelewatan waktu istirahat } \\
\text { karena terlalu asyik menonton } \\
\text { Observasi : } \\
\text { Tertawa malu sambil sesekali } \\
\text { memegang pipi dengan } \\
\text { tangan }\end{array}$ \\
\hline
\end{tabular}

\section{Pembahasan}

Celebrity worship (CW) bukan sekedar pemujaan penggemar biasa (Sasone \& Sasone, 2014), namun juga interaksi satu arah dimana individu terobsesi pada selebriti (McCutcheon, Ashe, Houran, \& Maltby, 2003). Hasil dalam penelitian ini mendukung teori CW dari Matlby, Day, McCutcheon, Horan \& Ashe (2006) dimana semakin tinggi tingkat CW, maka semakin intens pula frekuensi dan intesitas perilaku yang mencerminkan kecintaan individu terhadap idola. Perilaku yang ditunjukkan pada tingkat $\mathrm{CW}$ yang lebih tinggi tidak menggantikan perilaku yang muncul pada tingkat lebih rendah, tetapi meningkat secara bersama-sama secara lebih intens (McCutcheon, Lange, \& Houran, 2002). Misalnya perilaku menonton konser dengan frekuensi lebih tinggi pada R2 dengan tingkat borderline-pathological (tinggi) dibandingkan dengan R1 dan R3.

Peningkatan intensitas dan frekuensi perilaku CW yang ditunjukkan oleh subjek dapat dijelaskan melalui teori absorpsi-adiksi (McCutcheon, Lange, \& Houran, 2002). Pada tahap absorpsi, individu memberikan atensi secara sukarela terhadap informasi terkait idola yang menghasilkan peningkatan sense of reality dan memunculkan perasaan khusus terhadap idola (Cheung \& Yue, 2018). Hal ini lah yang menyebabkan munculnya dorongan untuk mempelajari lebih dalam mengenai idola. Pada individu dengan kapasitas absorpsi tinggi, terjadi identifikasi yang berlebihan terhadap idola dan munculnya perilaku obsesif (Brooks, 2018) berupa pencarian informasi yang berpindah ke tahap yang lebih intens seperti bertemu dengan orang yang memiliki informasi lebih dalam tentang idola (McCutcheon, Lange, \& Houran, 2002). Selanjutnya, kekuatan dorongan yang muncul pada tahap absorpsi menyebabkan individu mengembangkan komponen adiksi berupa ambang toleransi pada kegiatan $\mathrm{CW}$ di tingkat lebih rendah, sehingga individu melakukan kegiatan yang lebih ekstrim untuk dapat memberikan kepuasan yang sama atas kebutuhan informasi tentang idola (Maltby, Day, McCutcheon, Houran, \& Ashe, 2006). Perilaku CW yang obsesif memberikan dampak negatif seperti boros hal keuangan karena terus menerus membeli merchandise idola yang disebabkan adanya rasa bersalah terhadap idola jika tidak membeli (Reeves, Baker, \& Truluck, 2012), kesehatan secara menyeluruh (kelelahan fisik, depresi, kecemasan, gejala somatis) dan afek negatif (stres, rendahnya afek positif, kepuasan hidup) (Maltby, et al., 2004) seperti yang dirasakan oleh subjek. 
Pada aspek hubungan sosial, Kpop digunakan sebagai salah satu media dalam interaksi sosial yang merupakan ciri dari perilaku CW pada tingkat entertainmentsocial (rendah) (Brooks, 2018). Perilaku ini tetap muncul pada individu dengan tingkat CW yang lebih tinggi secara lebih intens (McCutcheon, Lange, \& Houran, 2002). Penggunaan Kpop untuk mengawali interaksi sosial yang ditunjukkan oleh R1 dan R2 sejalan dengan penelitian sebelumnya dimana pada tingkat intense-personal (sedang) dan borderline pathological (tinggi), individu cenderung menunjukkan identitas diri yang kabur sehingga memunculkan kebutuhan akan pembentukan struktur diri dan organisasi. Dengan membangun hubungan yang intens dengan kelompok sosial yang juga mengkhususkan diri terhadap idola tersebut, maka individu akan mendapatkan konsep diri yang lebih jelas dan menurunkan identitas kabur yang ia miliki (McCutcheon, Ashe, Houran, \& Maltby, 2003).

Padatingkatentertainment-social(rendah) dan intense-personal (sedang), perilaku CW dianggap normal dan dapat meningkatkan interaksi sosial dan memberikan kesenangan atau hiburan (Reeves, Baker, \& Truluck, 2012). Hal ini dapat membantu dewasa awal dalam memenuhi tugas perkembangan dalam aspek hubungan sosial yaitu hubungan yang intim baik dalam lingkungan pertemanan maupun keluarga (Bentley, 2007) seperti yang dirasakan oleh R1 dan R3. Sedangkan pada tingkat borderline-pathological (tinggi) individu menjadi terlalu asik dengan dunianya sendiri (McCutcheon, Lange, \& Houran, 2002) dan memunculkan perilaku disosiatif (Zsila, McCutcheon, \& Demetrovics, 2018) yang menyebabkan ia terlepas dari kehidupan sosial di dunia nyata (Greenwood \& Long, 2011). Hal ini tecermin dari R2 dengan berdiam diri di kos selama beberapa hari secara berturut-turut dan menolak ajakan teman sebaya untuk bersosialisasi.
Selain itu, individu dengan tingkat CW yang tinggi tidak terhubung dengan lingkungan sosialnya namun mengungkapkan bahwa dirinya bersikap terbuka dan dapat menerima perbedaan orang lain (Houran, Navik, \& Zerrusen, 2005). Perilaku ini terlihat pada R2 dengan tingkat borderline-pathological (tinggi), namun tidak muncul pada subjek dengan tingkat $\mathrm{CW}$ yang lebih rendah. Hal ini terjadi karena individu memiliki standar yang ketat tentang bagaimana sesuatu seharusnya terjadi, namun tidak didukung dengan perilaku yang ia tunjukkan secara aktual (McCutcheon, Aruguete, McCarley, \& Jenkins, 2016).

Temuan lain dalam penelitian ini adalah adanya ketidakmampuan dalam menyesuaikan perilaku CW meskipun adanya respon negatif dari lingkungan yang hanya ditunjukkan oleh R2 dengan tingkat borderlinepathological (tinggi). Perilaku ini berkaitan dengan fleksibilitas kognitif dimana subjek dengan tingkat $\mathrm{CW}$ yang tinggi menunjukkan adanya kekakuan dalam proses kognitif. Fleksibilitas kognitif didefinisikan sebagai kemampuan individu untuk menyesuaikan strategi pemrosesan kognitif saat terdapat situasi baru yang tidak terduga (Canas, Fajardo, \& Salmeron, 2005). Lebih lanjut lagi, Canas, Fajardo \& Salmeron (2005) menjelaskan bahwa proses penyesuaian terjadi setelah individu melakukan perilaku selama beberapa waktu dan mendapatkan respon yang tidak sesuai dari pada situasi baru. Kemampuan ini yang menyebabkan individu kompeten secara interpersonal (Brown, 2015). Kekakuan kognitif atau cognitive inflexibility inilah yang menghambat R2 dalam membangun hubungan sosial yang mendalam dengan orang lain. Sedangkan hubungan sosial pada dewasa awal yang mensyaratkan adanya penyesuaian antara perasaan, keinginan, dan kebutuhan pribadi dan orang lain dalam berinteraksi (Bentley, 2007).

Selanjutnya, respon negatif dari lingkungan sosial terhadap R2 membawa 
dirinya pada rasa kesepian dan perasaan terkucilkan. Hal tersebut merupakan tanda dimana individu mengalami krisis tugas perkembangan dewasa awal (Santrock, 2017). Meskipun begitu, R2 menyatakan bahwa dengan terus terhubung dengan idola-idolanya melalui kegiatan $\mathrm{CW}$ mampu melengkapi rasa kesepian yang ia rasakan. Hal ini menunjukkan bahwa hubungan yang tercipta dengan idola dipandang sebagai alternatif sumber companionship sebagai kompensasi dari rasa kesepian yang mereka rasakan akibat kurangnya hubungan yang mendalam dengan lingkungan sosial (Kurtin, O'Brien, Roy, \& Dam, 2019).

Pada aspek hubungan romantis, dewasa awal dituntut untukmempunyai hubunganyang bersifat stabil dan berorientasi pada komitmen jangka panjang (Pettit, Lansford, Bates, \& Dodge, 2013). Untuk dapat memenuhinya, individu harus membuka diri dan berkorban untuk orang lain. Meskipun begitu individu harus realistis dengan mengukur resiko kekecewan dan rasa sakit yang dapat ia atasi (Bentley, 2007). Hal ini merupakan hal yang menantang, khususnya bagi individu yang memiliki kekhawatiran dalam hal penerimaan (Greenwood \& Long, 2011) seperti pada R2 atau kurang memiliki pengalaman dalam menjalin hubungan romantis (Rauer, Pettit, Lansford, Bates, \& Dodge, 2013) seperti pada R1 dan R3. Dalam hal ini CW terhadap idola memberikan pemenuhan intimacy yang aman, mudah (Greenwood \& Long, 2011), dan dengan resiko penolakan rendah karena tidak membutuhkan investasi emosional seperti pada hubungan di dunia nyata yang bersifat dua arah (Darfiyanti \& Putra, 2012).

Pada R1 dan R2, kegiatan CW juga bertujuan untuk mengurangi rasa kesepian yang mereka rasakan karena belum memiliki pasangan. Rasa kesepian lebih intens dirasakan oleh R2 dengan tingkat borderlinepathological (tinggi). Kekhawatiran dan rasa kesepian yang tinggi menyebabkan individu menggunakan $\mathrm{CW}$ sebagai tempat untuk pelarian dari tuntutan hidup (Brown, 2015). Dalam hal ini ditunjukkan dari perilaku R2 yang lebih nyaman dengan kondisinya sekarang dibandingkan dengan memulai hubungan nyata yang baru.

Untuk menghilangkan rasa kesepian, R1 dengan tingkat intense-personal (sedang) dan R2 dengna tingkat borderlinepathological (tinggi) memunculkan fantasi bahwa idola adalah soulmate. Fantasi muncul sebagai akibat dari adanya proses pemberian atribut atau karakteristik tertentu pada idola, pemaparan, dan interaksi dengan lingkungan secara berulang pada kegiatan imajinatif yang menyebabkan hubungan tersebut seolaholah menempati ruang fisik atau realitas yang pada akhirnya membuat fantasi tersebut masuk dan dianggap sebagai hubungan yang sebenarnya (Kurtin, O’Brien, Roy, \& Dam, 2019). Selain itu, proses tersebut juga pada akhirnya memunculkan rasa familiaritas, kedekatan, kepedulian, dan ketertarikan kepada idola (Stever, 2011). Familiaritas juga menyebabkan proses kognisi tidak lagi dapat membedakan perbedaan antara pengalaman yang terjadi di dunia nyata dan yang dialami melalui media (McCutcheon, Aruguete, McCarley, \& Jenkins, 2016), khususnya pada R2 yang tidak dapat membedakan rasa suka terhadap idola dan orang di dunia nyata. Hal ini mendukung penelitian sebelumnya dimana CW pada tingkat intense-personal (sedang) dan borderline pathological (tinggi) berhubungan positif dengan fantasy proneness (Maltby, Day, McCutcheon, Houran, \& Ashe, 2006). Selain berdampak pada munculnya fantasi, kegiatan imajinatif secara berulang juga membuat individu mengembangkan konsep pasangan ideal yang tidak realistis di dunia nyata (Brown, 2015) seperti yang ditunjukkan oleh R2.

Munculnya fantasi yang menyebabkan tingginya standar pasangan ideal dan pelarian yang dilakukan khususnya pada R2 dengan tingkat borderline pathological (tinggi) menunjukkan sikap tidak realistis yang 
ditunjukkan individu. Sedangkan hubungan romantis pada dewasa awal umumnya bersifat realistis yang ditandai dengan adanya kesadaran atas hal-hal yang dapat dicapai dan tidak (Bentley, 2007). Hal ini dapat mengganggu individu dalam mencapai tugas perkembangan untuk membangun intimacy pada dewasa awal.

Pada R3 dengan tingkat entertainmentsocial (rendah), penundaan dalam memiliki pasangan karena ingin fokus pekerjaan dapat terjadi pada dewasa awal. Penundaan ini biasa ditemukan pada individu yang memprioritaskan diri pada pengembangan potensi pribadi. Hal ini dapat memberikan manfaat positif karena memberikan waktu bagi dewasa awal untuk mempersiapakan kualitas diri (Shulman \& Connolly, 2013).

Pada aspek pekerjaan, adanya upaya untuk mengembangkan hobi yang berkaitan dengan Kpop ke arah yang lebih serius dan menjadikan Kpop sebagai inspirasi dalam pekerjaan menunjukkan adanya eksplorasi yang dilakukan oleh $\mathrm{R} 1$ dan $\mathrm{R} 3$ sebelum menemukan karir yang sesuai dengan minat dan kemampuan mereka. Adanya eksplorasi dalam identitas karir merupakan salah ciri dari tugas perkembangan dewasa awal (Arnett, 2014). Namun, pemilihan karir juga dipengaruhi oleh faktor lain seperti preferensi individu, tuntutan sosial dan ekonomi serta gambaran pekerjaan ideal yang terdapat pada budaya tertentu (Grosemans, Hannes, Neyens, \& Kyndt, 2018). Preferensi akan karir yang lebih stabil inilah yang membuat R2 memilih untuk tidak mejadikan Kpop sebagai pilihan pekerjaannya.

\section{Kesimpulan}

Hasil penelitian menunjukkan bahwa perilaku celebrity worship (CW) yang ditunjukkan oleh subjek dapat dijelaskan dengan proses absorpsi-adiksi. Penyerapan informasi pada tahap absorpsi meningkatkan sense of reality yang memunculkan dorongan untuk terus mencari informasi terkait idola.
Pada individu dengan tingkat absorpsi yang lebih tinggi, dorongan ini dapat mendukung munculnya perilaku obsesif. Pada titik tertentu, hal ini memunculkan komponen adiksi dimana kegiatan yang $\mathrm{CW}$ yang dilakukan untuk mendapatkan informasi tidak lagi dapat memberikan kepuasan sehingga individu beralih pada kegiatan yang lebih ekstrim untuk mendapatkan kepuasan yang sama.

Selain itu, ditemukan pula bahwa pada CW memainkan peran penting pada dua aspek tugas perkembangan dewasa awal yaitu dalam hubungan sosial dan hubungan romantis. CW pada tingkat borderlinepathological (tinggi) menghambat subjek untuk menyelesaikan tugas perkembangan dalam membangun hubungan sosial yang mendalam. Hal ini disebabkan adanya perilaku disosiatif atau penarikan diri dari lingkungan sosial karena tenggelam dalam kegiatan CW. Selain itu, hambatan yang ditunjukkan oleh subjek dengan tingkat borderline-pathological (tinggi) juga disebabkan karena adanya kekakuan kognitif atau cognitive inflexibility berupa ketidakmampuan subjek untuk menyesuaikan perilakunya dengan situasi dan tuntutan sosial yang berbeda. Sebagai dampaknya, individu masuk ke dalam krisis perkembangan yang yaitu kesepian dan rasa terkucilkan. Namun hal in tidak ditemukan pada subjek dengan tingkat yang lebih rendah. Selanjutnya, pada aspek hubungan romantis, meskipun fantasy proneness muncul pada tingkat intense-personal (sedang) dan borderline-pathological (tinggi), namun dampak negatif hanya dirasakan pada subjek di tingkat borderline-pathological (tinggi) dimana fantasi yang ekstrim dan perilaku obsesif yang menyakinkan diri bahwa individu memiliki hubungan khusus dengan idola membuatnya tidak dapat lagi membedakan rasa suka kepada idola dan pada orang di dunia nyata sehingga tidak ingin mencari pasangan sebenarnya. Hal ini ini tidak ditemukan pada subjek dengan 
tingkat lebih rendah. Selanjutnya, pada aspek pekerjaan, CW tidak memberikan dampak yang dalam pemilihan jenis pekerjaan subjek.

Pada penelitian ini didapatkan hasil bahwa tidak hanya perilaku disosiatif, permasalahan dalam hubungan sosial pada dewasa awal dengan tingkat borderline-pathological (tinggi) disebabkan oleh permasalahan fleksibilitas kognitif. Hal ini ditunjukkan dengan perilaku individu yang tidak dapat menyesesuaikan perilakunya dengan situasi dan tuntutan sosial berbeda karena fokus pada standar idealnya sendiri. Sedangkan pada dewasa awal, individu harus dapat berkompromi dan memahami kebutuhan orang lain agar hubungan yang dalam dapat tercapai. Namun, terdapat keterbatasan dalam generalisasi hasil studi karena menggunakan metode kualitatif. Dengan temuan ini, penelitian selanjutnya diharapkan dapat melihat hubungan dan peran dari fleksibilitas kognitif pecinta Kpop terhadap pemenuhan tugas perkembangan khususnya dalam hal hubungan sosial.

\section{Daftar Pustaka}

Arnett, J. J. (2014). Emerging Adulthood: The Winding Road from the Late Teens Through the Twenties. New York: Oxford University Press, Inc.

Bentley, E. (2007). Adulthood: Developmental Psychology. Canada: Routledge.

Braun, V., \& Clarke, V. (2012). Using Thematic Analysis in Psychology. In $\mathrm{H}$. M. Cooper, APA handbook of research methods in psychology. Vol. 2, Research designs : quantitative, qualitative, neuropsychological, and biological (pp. 57-71). Washington, D.C: American Psychological Association.

Brooks, S. K. (2018). FANatics: Systematic literature review of factors associated with celebrity worship, and suggested directions for future research. Current Psychology.

Brown, W. J. (2015). Examining Four Processes of Audience Involvement
With Media Personae:Transportation, Parasocial Interaction, Identification, and Worship. Communication Theory, 259283.

Cahyani, D., \& Purnamasari, Y. (2018). Celebrity Worship on Early Adult K-Pop Fangirling. Advances in Social Science, Education and Humanities Research, 77-89.

Canas, J. J., Fajardo, I., \& Salmeron, L. (2005). Cognitive inflexibility and the development and use of strategies for solving complex dynamic problems: effects of different types of training. Theoretical Issues in Ergonomics Science, 1-14.

Cheung, C. k., \& Yue, X. D. (2018). Idols as Sunshine or Road Signs: Comparing Absorption-Addiction Idolatry With Identification-Emulation Idolatry. SAGE, 1-22.

Creswell, J. W., \& Poth, C. N. (2018). Qualitative Inquiry \& Research Design Fourth Edition. USA: SAGE Publications, Inc.

Darfiyanti, D., \& Putra, B. A. (2012). Pemujaan terhadap Idola Pop sebagai Dasar Intimate Relationship pada Dewasa Awal: sebuah Studi Kasus. Jurnal Psikologi Kepribadian dan Sosial Vol.1, 53-60.

Dewi, D. P., \& Indrawati, K. R. (2019). Gambaran celebrity worship pada penggemar K-Pop usia dewasa awal di Bali. Jurnal Psikologi Udayana, Vol. 6, No. 2, 91-300.

Envira, R. (2019). Hubungan antara Pemujaan Selebriti dan Gejala Depresi pada Remaja Penggemar Idola Korea. Yogyakarta: Universitas Sanata Dharma.

Fandia, M. (2016, November 02). The Fandom for Idols - A Survey Report on Kpop Fans in Indonesia. Retrieved Januari 23, 2021, from https://blog.jakpat.net/the-fandomfor-idols-a-survey-report-on-kpop-fansin-indonesia/ 
Feist, J., \& Feist, G. J. (2018). Theories of Personality 9th Edition. New york: McGraw-Hill.

Greenwood, D. N., \& Long, C. L. (2011). Attachment, Belongingness Needs, and Relationship Status Predict Imagined Intimacy With Media Figures. Communication Research 38 (2), 278-297.

Grosemans, I., Hannes, K., Neyens, J., \& Kyndt, E. (2018). Emerging Adults Embarking on Their Careers: Job and Identity Explorations in the Transition to Work. Youth \& Society, 1-25.

Houran, J., Navik, S., \& Zerrusen, K. (2005). Boundary functioning in celebrity worshippers. Personality and Individual Differences, 237-248.

Kurtin, K. S., O'Brien, N., Roy, D., \& Dam, L. (2019). Parasocial Relationships with Musicians. The Journal of Social Media in Society, 30-50.

Lavesque, R. J. (2012). Idols and idolization. In R. J. Lavesque, Encyclopedia of Adolescence, Volume 1 (pp. 1377-1378). New York: Springer Science \& Business Media.

Lee, S. J. (2011). The Korean Wave: The Seoul of Asia. Elon Journal of Undergraduate Research in Communication, 85-93.

Liu, J. K. (2013). Idol worship, religiosity, and self-esteem among university and secondary students in Hong Kong. Discovery - SS Student E-journal, Vol.2, 15-28.

Maltby, J., Day, L., McCutcheon, L. E., Houran, J., \& Ashe, D. (2006). Extreme celebrity worship, fantasy proneness and dissociation: Developing the measurement and understanding of celebrity worship within a clinical personality context. Personality and Individual Differences 40, 273-283.

Maltby, J., Maltby, J., McCutcheon, L. E., Gillett, R., Houran, J., \& Ashe, D. D. (2004). Personality and coping: A context for examining celebrity worship and mental health. British Journal of
Psychology, 95, 411-428.

McCutcheon, L. E., Aruguete, M., McCarley, N. G., \& Jenkins, W. J. (2016). Further Validation of an Indirect Measure of Celebrity Stalking. Journal of Studies in Social Sciences Vol. 14, 75-91.

McCutcheon, L. E., Ashe, D. D., Houran, J., \& Maltby, J. (2003). A Cognitive Profile of Individuals Who Tend to Worship Celebrities. The Journal of Psychology,, 309-322.

McCutcheon, L. E., Lange, R., \& Houran, J. (2002). Conceptualization and Measurement of Celebrity Worship. British Journal of Psychology, 67-68.

Mushtaq, R., Shoib, S., Shah, T., \& Mushtaq, S. (2014). Relationship Between Loneliness, Psychiatric Disorders and Physical Health ? A Review on the Psychological Aspects of Loneliness. Journal of Clinical \& Diganostic Research, Vol-8(9), WE01-WE04.

Pettit, A. J., Lansford, J. E., Bates, J. E., \& Dodge, K. A. (2013). Romantic Relationship Patterns in Young Adulthood and Their Developmental Antecedents. Developmental Psychology, 2159-2171. Rahman, A. A. (2019). Online Fandom: Social Identity and Social Hierarchy of Hallyu Fans. The Journal of Undergraduate Ethnography, 9.

Rauer, A. J., Pettit, G. S., Lansford, J. E., Bates, E. J., \& Dodge, K. A. (2013). Romantic relationship patterns in young adulthood and their developmental antecedents. Developmental Psychology Vol.49 No.11, 2159 -2171.

Reeves, R. A., Baker, G. A., \& Truluck, C. S. (2012). Celebrity Worship, Materialism, Compulsive Buying, and the Empty Self. Psychology and Marketing Vol. 29 (9), 674-679.

Ri'aeni, I., Suci, M., Pertiwi, M., \& Sugiarti, T. (2019). Pengaruh Budaya Korea (K-Pop) terhadap Remaja di Kota Cirebon. Communications Vol. 1, No. 1, 1-26. 
Santrock, J. W. (2017). Life-Span Development 17th Edition. New York: McGraw-Hill Education.

Sasone, R. A., \& Sasone, L. A. (2014). "I'm Your Number One Fan"- A Clinical Look at Celebrity Worship. Innovation in Clinical Psychology Vol. 11, 39-43.

Shulman, S., \& Connolly, J. (2013). The Challenge of Romantic Relationships in Emerging Adulthood: Reconceptualization of the Field. Emerging Adulthood (1), 27-39.

Stever, G. S. (2011). an Behavior and Lifespan Development Theory: Explaining Para-social and Social Attachment to Celebrities. Journal of Adult Development 18, 1-7.

The Jakarta Post. (2020, September 23). Indonesians among K-pop's biggest fans: Twitter. Retrieved 01 23, 2021, from The Jakarta Post. (n.d.). Indonesians among K-pop's biggest fans: Twitter. Retrieved January 23, 2021, from https:// www.thejakartapost.com/life/2020/09/23/ indonesians-among-k-pops-biggestfans-twitter.html

Yeasmin, S., \& Rahman, K. F. (2012). 'Triangulation' Research Method as the Tool of Social Science Research. BUP Journal Vol. 1, 154-163.

Zsila, A., McCutcheon, L. E., \& Demetrovics, Z. (2018). The association of celebrity worship with problematic Internet use, maladaptive daydreaming, and desire for fame. Journal of Behavioral Addictions 7 (3), 654-664. 